\title{
Evaluating the retrofitting process for Imam (Soltani) Mosque monument after Silakhor Plan earthquake damage (31 March 2006)
}

\author{
H. R. Vosoughifar \\ Civil Engineering Department, Faculty of Technology, \\ Islamic Azad University, Tehran South Branch, Tehran, Iran
}

\begin{abstract}
In this paper the retrofitting process for Imam Mosque after Silakhor Plan Earthquake (31 March 2006) was evaluated. Retrofitting the historical structures or monuments has been a challenge for experts and authorities for years while no basic and integrated measure has been taken in this regard and with Bam earthquake and destruction of historical Arg-e-Bam and Seilakhor plain earthquake and damage incurred by historical places and heritage they are threatened to be destroyed. The earthquake tremors in Borujerd caused damage of various degrees in the historic and cultural buildings. In the city of Borujerd, the most significant damage included the damage of the minarets in the Jame' Mosque, the collapse of false ornamental stalactite ceiling in the Iamam (Soltani) Mosque and partial collapse of the beehive dome in the Imamzadeh Ja'far Shrine in the Lorestan province. The main damage in the Imam Mosque included collapse of the false ceiling including the rich stalactite ornament on the south eivan and cracking on the flanking parts of the north eivan. Destruction has resulted from the execution of a big concrete beam over the doorway that changed the behaviour of the same and made it rigid. In some cases incorrect retrofitting would lead to structural damage at the time of an earthquake. The concrete tie-beam on the south eivan of Imam Mosque has aggravated the impact of an earthquake on the structure as, during construction, the keystone of the original arch has also been weakened. This tie-beam should be replaced by a more resilient system of reinforcement. Moreover, terms of reference for cooperation between restoration and retrofitting of the monuments should be drafted specifically for each monument according to the particular conditions prevailing in each case.
\end{abstract}

Keywords: retrofitting, Imam Mosque, restoration, earthquake. 


\section{Introduction}

In recent years many monuments have been damaged by earthquakes in Iran. The residents of the ancient city of Bam in southeast Iran slept as 26 December 2003 began. By 5:26 am, the city lay in ruins, shattered by an earthquake that lasted just $10 \mathrm{~s}$ and measured 6.5 on the Richter scale, devastating more than $90 \%$ of the city centre and historic buildings [1]. An important cultural loss was the almost total destruction of the well-known historic citadel Arg-e-Bam. This monument, declared by UNESCO as a World Heritage Site, is the biggest mudbrick structural complex in the world. The structure was well intact before the 2003 Bam earthquake [10]. The historic monument of Arge Bam, parts of which date back 2000 years, was severely damaged. With an area of $220,000 \mathrm{~m}^{2}$, it includes 25 distinct monuments comprising residential, social, educational and commercial buildings, a military camp, mosques, bazaar, school, prison, sports centre, ice house and the governor section, surrounded by 2,000 $\mathrm{m}$ of walls up to $18 \mathrm{~m}$ high [15]. Many researchers have analyzed this monument and they wrote a lot of scientific papers about historic buildings and earthquakes. This earthquake and its effect on Arge Bam created a new viewpoint in Iran for monument disaster management including pre disaster, in event management and post event disaster management. In pre event disaster management retrofitting and restoration are introduced. Structural preservation of historic buildings in seismic areas has evolved to become one of the important and relatively new issues in earthquake engineering. It encompasses the identification of the existing structural system and materials used [6] in the construction, including zones of previous repair [2], weakness, cracking and other structural discontinuities, linear and non-linear dynamic analysis, ambient vibration testing, soil and foundation investigations and the strong instrumentation of the monument [8]. On the basis of all these experimental and analytical investigations, alternatives of structural interventions towards the improvement of its structural worthiness can be formulated.

\section{Damage index}

There are numerous types of damage scales with various attributes, qualities, difficulties or advantages. The seismic damage index is based on buildings damaged or destroyed by earthquakes. By identifying the damage index of a monument structure, in addition to a correct understanding from real behaviour of the structure, the required criterion for retrofitting would be given. Researchers have given many relations for determination of the damage index. Giving an index for failure is a subject that has attracted researchers' attention for more than three decades. For this purpose and knowing the failure indices of a structure we may understand the structure behaviour in a correct way and apply it to regulate its risky margins. On the other hand to control the current condition of a structure the knowledge of its failure method would be necessary for giving an improvement plan. In other words, finding a damage index in a structure 
make it clear that to what level the given structure would resist against side forces like earthquakes.

The background of activities that have taken place for determination of the damage index goes back to the early years of the 1970s. In 1972, Whitman showed using the ground movement intensity and damage of buildings upon the ratio of expenses and repair [21]. In 1979 and upon two qualitative criterion, final deformation and coefficients of effects, another method was given by Bertero and Brokken [4]. In 1985, Park and Ang gave a newer method upon maximum possible deformation of a member and final deformation with their combination with the maximum absorbed energy [17]. In 2000, Iemura and Mikami showed that the damage index should be considered before structure analysis and during the application of structural limitations [11]. They gave a new relation based on the Park and Ang relation [17] and the level of ductility [11]. In 2001, Honglin et al., gave a modern method based on collected data from a GIS system. This method was an innovation upon which the damage index was evaluated in an area in a qualitative manner. In the same year, Bozorgnia and Bertero gave two separate indices of structure damage for structures. Such relations have been clearly compiled with the performancebased design [5]. In 2003 Reinhorn and Valles defined a damage index upon which the fatigue is directly incorporated in calculations [19]. In 2003, Papadopoulos et al., with a simple and accurate method introduced an exact method for calculation of the damage index which is quicker and simpler than prior methods [16]. In 2005, Colombo and Negro gave a method for calculation of the damage index, which has been used independently from material [7]. Lourenc and Roque performed an investigation about the possibility of using simplified methods of analysis and simple indexes as indicators for fast screening and decided to prioritize deeper studies in historical masonry buildings and assess vulnerability to seismic actions. These indexes are based mostly on the in plan dimensions and height of the buildings. The simplified methods indicate that, in Portugal, the average in plan area of earthquake resistant walls and average height are independent of the seismicity. This puzzling feature can be related to the short memory of the ancient builders and the fact that major earthquakes in Portugal have rather long return periods (over 200 years) [13].

\section{Typical damage in monuments}

An analysis of the damage survey of historical masonry buildings for the Umbria-Marche earthquake [9] shows that the problem is generalized and that structural typologies, as well as associated type and distribution of damage, are fairly recurring. Vulnerability may be reduced through retrofitting/protection to better resist the seismic demand.

Anti-seismic action requires the knowledge of seismic site response, the definition of the seismic load (a rather challenging issue) and the knowledge of the characteristics of existing buildings. This is a gigantic task, requiring large funds and considerable large time-span, but several efforts have been made to create damage scenarios and to prioritize retrofitting works, e.g. [3, 12]. 
A review of the historical sources in Iran, supported by present day knowledge of earthquake engineering, shows that, as far as the earthquake damage is concerned, the slender, free standing members of a complex are in the first line of an earthquake. Minarets, wind towers and high portals of eivans and entrance halls are amongst the weakest members. There are numerous references to the collapse of minarets and high portals in past earthquakes. There are in fact very few old minarets, which have not undergone extensive restoration or reconstruction in the areas of higher seismic activities. Remnants of partially toppled minarets, particularly those integrated within the building, are frequently seen in the old mosques. The collapsed minarets of the grand mausoleum of Sultanieh in Zanjan, the Jami mosque in Ashtarjan, Jami mosque of Kerman and the formerly Shah Mosque in Mashhad are some examples. It should be noted that the response of a tall slender structure, such as a minaret, during an earthquake depends primarily on the frequency contents of the ground shaking. A low frequency, distant shock may easily topple a minaret or a slender tower, but a high frequency local shock may affect the main building more than the minaret. An example of this behavior is the minaret of Bagh-i Qushkhane in Isfahan, the only section of a large building still remaining. High portals of entrance halls and eivans have also performed weakly in earthquakes. The upper parts of these portals are effectively, free standing slender elements, susceptible to low frequency ground shaking, in a direction perpendicular to the portal. Collapse of the upper part of the high portal of Jami mosque in Gunabad (built in 13th century AD) during the devastating earthquake of Aug 31st $1968(\mathrm{M}=7.4)$ is a more recent event [14].

\section{Silakhor Plan earthquake and monuments}

On 31 March 2006, a series of earthquakes with the strongest shock measuring 6 on the Richter scale (according to Iran Geophysics Centre) struck south-western Iran and affected the cities and villages around Borujerd Lorestan Province. The seismic jolt caused extensive damage in many villages and the city of Borujerd. There are about 40 cultural heritage properties which have sustained damage of various degrees in the earthquake-stricken area. The earthquake epicentre was in Darb-e-Astaneh a remote village about 40 kilometres west of the city of Dorud. The series of seismic shocks however affected a vast populated rural and urban area: some 25 villages and the city of Borujerd were severely damaged. Telephone lines, electricity and gas supplies had been cut in some areas. The city of Borujerd dates to the ancient history of Iran. Containing approximately 40 cultural heritage properties, it boasts most of the cultural building property in the whole Lorestan province. The earthquake tremors in Borujerd caused damage of various degrees in the historic and cultural property of the province. In the city of Borujerd, the most significant damage includes the damage of the minarets in the Jame' Mosque, the collapse of false ornamental stalactite ceiling in the Iamam (Soltani) Mosque and partial collapse of the beehive dome in the Imamzadeh Ja'far Shrine. In the Lorestan province, Imamzadeh Khaled Ibn Ali, Hojatieh School, Ghaleh and Rangineh Mosques were also damaged. Many of the old 
historic houses were also damaged in the historic fabric of borujerd. However, rapid urbanization and building activities during the past three decades have caused soaring land prices and created the tendency to convert the cultural and historic property into modern apartment buildings accessed by wide streets. Lack of vehicular access in the old fabric, lack of proper maintenance, misuse or inappropriate upkeep and use, and Government policies favouring modern building types and technologies, all contributed to deterioration of the historic fabric. Accordingly, much of the old historic fabric was already demolished before the earthquake.

\subsection{Imam (Soltani) Mosque}

Soltani Mosque of Borujerd was known as Masjed Shah in the Pahlavi Dynasty and today it is called Masjed-e Imam Khomeini. This mosque registered in the National Heritage List (ID number 394), the Imam (formerly Soltani) Mosque has been built in the early Qajar period (circa 1830 AD). Designed after the Imam (formerly Shah) Mosque of Tehran, the monument has been designed as a combination of a Mosque and a theological school with 16 small rooms (hojreh) to accommodate theological students. The faience ornament used in this monument is among the unique samples of Qajar tiles. The older mosque was probably built in 10th century A.D. Soltani means related to Sultan which refers to Fath Ali Shah Qajar who ordered the rebuilding of this building.

\subsection{Damage in Imam Mosque}

The main damage in the Imam Mosque includes the collapse of the false ceiling including the rich stalactite ornament. The south eivan and of the north eivan. This damage is shown in figure 1 .

In the retrofitting process increased stiffness creates a negative effect for the building's seismic performance. Other intervention strategies may aim at producing other types of change in the structural behavior, such as increasing the energy dissipation capacity, by means of specific devices, or decreasing the inertia forces, for instance by means of base isolation. It is therefore important that the choice of a seismic upgrading strategy considers all the changes in structural behavior it may induce. Moreover, it is very important to know how the solutions adopted influence the seismic resistance of different collapse mechanisms [20]. Destruction shown in the figure 2(a) has resulted from the execution of a big concrete beam over the doorway that changed the behaviour of the same and made it rigid. As is seen, in some cases incorrect retrofitting would lead to structural damage at the time of earthquake. Retrofitting methods should be based on improvement of elasticity of the structure and those methods that increase the rigidity of structure are not suitable solutions for seismic reconstruction. Figure 2(b) shows for performance that this tie beam arch keystone was destroyed. This matter and the tie beam impact increased damage in the north eivan. In the repair process, conductors and consultants must consider seismic load and they must design and repair with special brick with a lock system. 
South eivan (Major Damage)

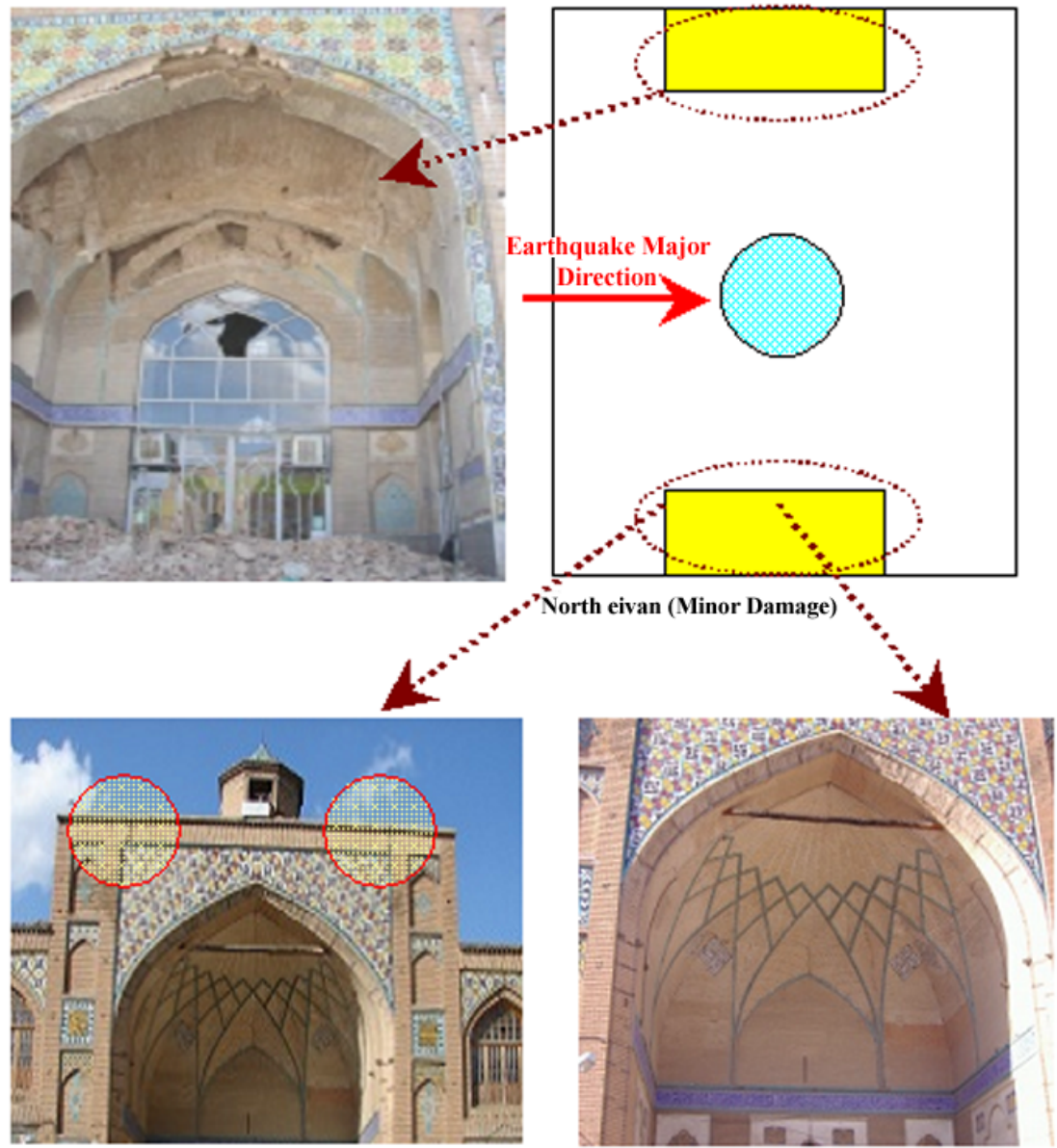

The symmetrical cracks on the flanking parts

Figure 1: Ornament collapse in the south and north eivan.

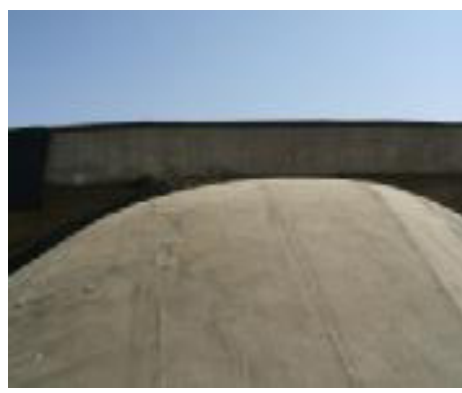

(a) the solid concrete tie-beam

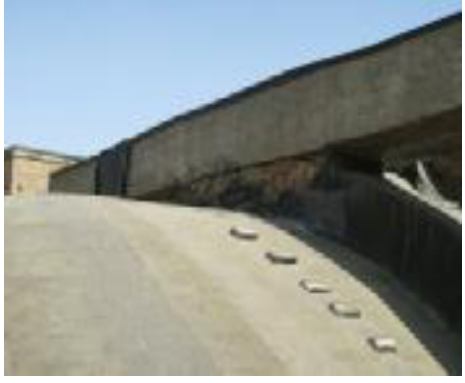

(b) Damage in Arch keystone

Figure 2: The solid concrete tie-beam over the main arch in the south eivan.

WIT Transactions on The Built Environment, Vol 93, (c) 2007 WIT Press www.witpress.com, ISSN 1743-3509 (on-line) 
The concrete tie-beam on the south eivan of Imam Mosque has aggravated the impact of the earthquake on the structure as during the construction the keystone of the original arch has also been weakened. This tie-beam should be replaced by a more resilient system of reinforcement.

Figure 3 shows the effect of the concrete tie beam on dynamic behaviour of south eivan of Imam Mosque. This beam prevents flexible behaviour and this has caused more damage in the south eivan than the north eivan.

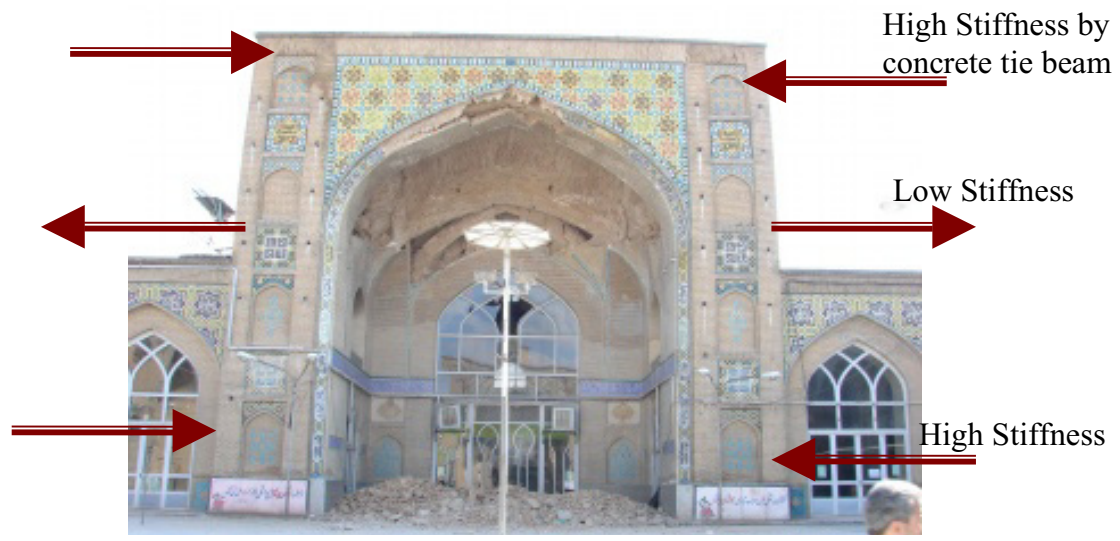

Figure 3: $\quad$ Effect of concrete tie beam on dynamic behaviour.

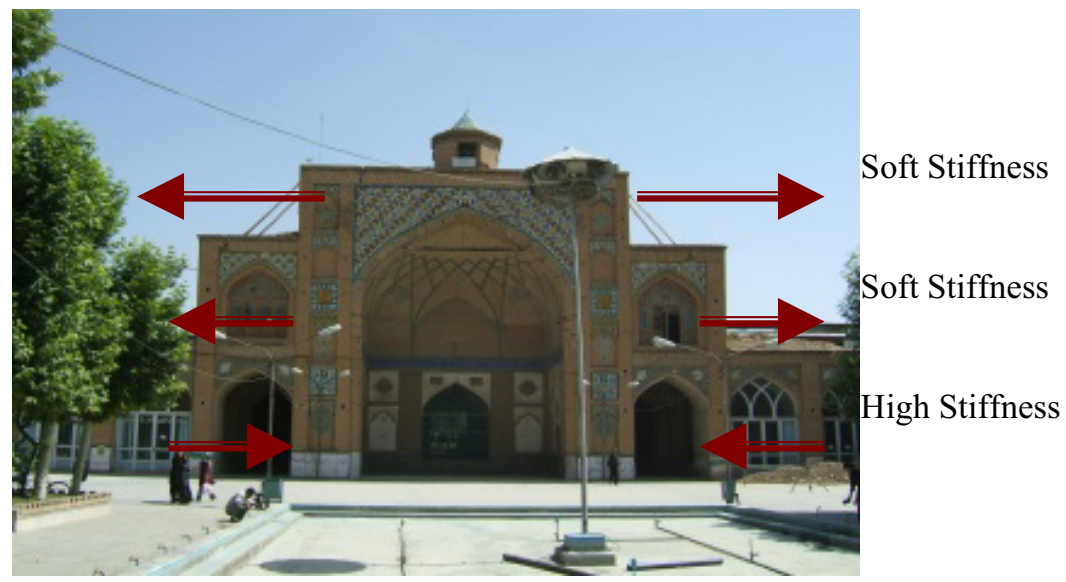

Figure 4: The north eivan after the earthquake.

Figure 4 shows north eivan behaviour against earthquake. This eivan had soft, flexible and suitable dynamic behaviour.

The earthquake has damaged the intermediary structures between the vaults and the finished floor opening the way for penetration of water. Internal decorations in particular the mihrab inscribed in the Imam Mosque are more exposed to water damage. Figure 5 shows water seepage in this monument. 

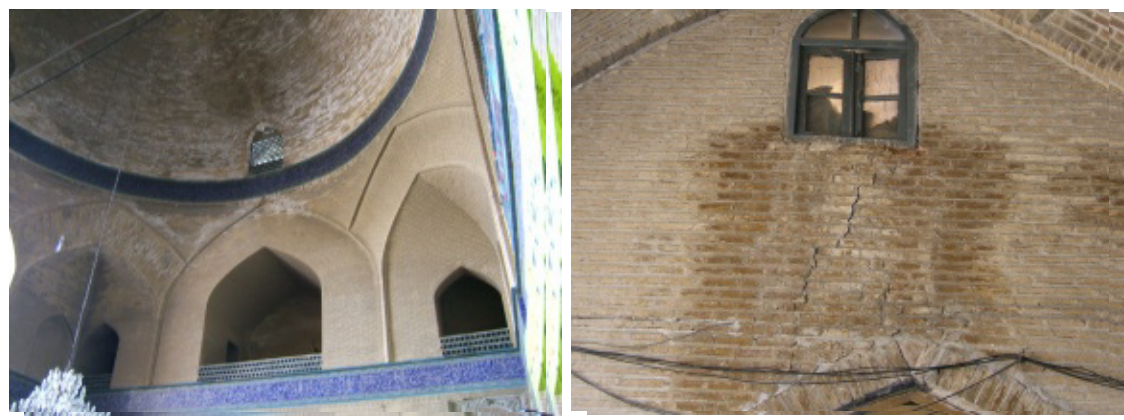

Figure 5: Water damage after earthquake.

\section{Retrofitting process}

The subject of retro-fitting and seismic retrofitting of historical and heritage buildings is a very new subject in Iran. The knowledge of the repair and conservation of these buildings is old, and sufficient experience exists in this area. However, combining the two branches of knowledge and experience in the fields of seismic retrofitting, conservation, and repair, especially for old historical ornamental buildings made of masonry and adobe material is a new subject with little theoretical and field experience all over the world and especially in Iran.

An iterative method is proposed for the seismic assessment of old masonry buildings. In each stage damage in the structural elements or connections between elements due to collapse (brittle behavior) or yielding (ductile behavior) are identified and the structural system changed accordingly [18].

Besides the seismic intensity at collapse, the method allows the identification of the weakest links and connections in the structure and the identification of its expected collapse mechanism, which are relevant information to the design of seismic retrofitting solutions. The proposed method is conservative, as it does not account for the energy dissipation capacity, which is likely to be underestimated by means of using an equivalent linear damping coefficient, and overestimates the effects of the seismic action, as it does not account for its duration. It cannot be applied to regular block masonry, as it cannot simulate the behavior of the interfaces and the geometrical non-linearity. In general case retrofitting process is shown in figure 6 .

Given the type of mortar used in the monuments penetration of water can cause several kinds of damage: changing colour; damage to ornament; and increasing structural weaknesses at earthquake time. In Imam Mosque the dampproof measures to protect the building against the humidity are ineffective and have further aggravated the situation. There is a need to replace the bituminous mats by an appropriate method in line with the traditional water insulation techniques. There is a need to provide temporary light-weight roofing (corrugated sheets) for emergency protection of the roofs against the coming autumn precipitation. This might be used as a general approach for all parts of 
roof, if time constrains encourages it. Contractors of Imam Mosque involved in repairing the roofing, need to be warned not to dump debris on the roofs. This may cause new visible or invisible damage.

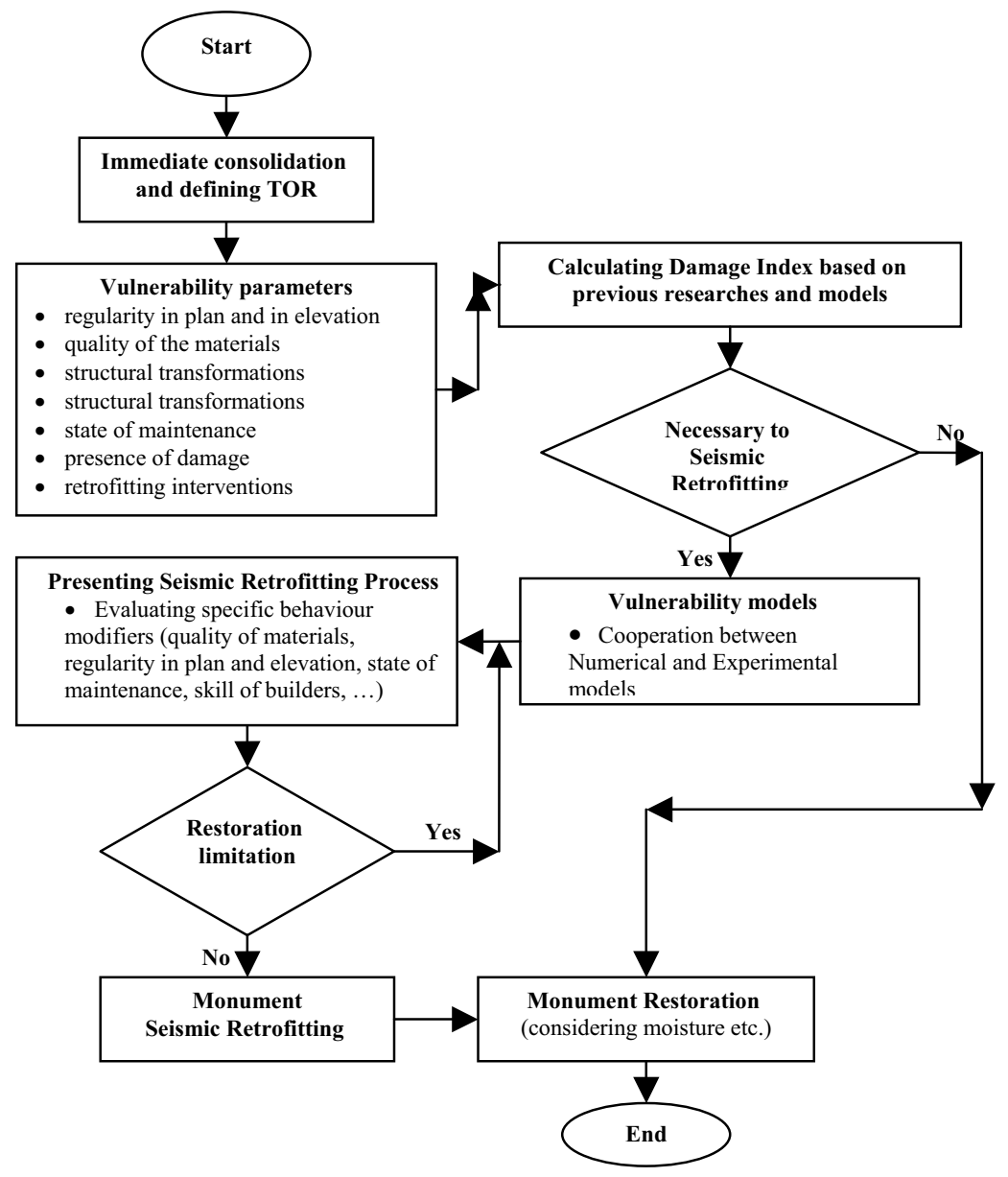

Figure 6: Retrofitting process in monuments.

\section{Results}

- Terms of References (TOR) for restoration and consolidation of the monuments should be drafted specifically for each monument according to the particular conditions prevailing in each case. The ToRs for Imam Mosque should specifically include the following services:
a.
Calculating quality and quantity seismic damage index
b.
Reducing major risk of structure
c.
Investigating dangerous and structural cracks 
$\begin{array}{ll}\text { d. } & \text { Reducing stiffness of tie beam } \\ \text { e. } & \text { Damp-proof insulation }\end{array}$

- Protected core zone. Each monument has a protected area. In the case of Imam Mosque, the new roofing of Bazaar, with corrugated sheets had destroyed the original fabric of Bazaar and has damaged the urban landscape and assaulted the historic buildings along the bazaar.

- In Imam Mosque severe damage has been incurred by the main rib arches (tavizeh) at the front façade of eivans. In addition to the earthquake forces the weakness of structures due to the poor use of bricks (jack-arch or zarbi, instead of vaulting or rumi) had aggravated the situation.

- Seismic strengthening projects are specialized works, which need a thorough knowledge and experience in this field. It is not a type of work that any novice can easily participate in. Therefore, the qualifications of the engineers and contractors should be evaluated and approved by the Committee of Experts as discussed in Item 3 above, and the projects should be assigned to qualified organizations. Of course, the door should remain open for future engineers and contractors to gradually enter this field.

- Tie beam on dynamic behaviour of south eivan of Imam Mosque prevents flexible behaviour and this has caused more damage in south eivan than north eivan. Therefore mistakes in the retrofitting process will cause increased damage at earthquake time.

\section{References}

[1] Akbari M.E., Farshad A.A., Asadi-Lari M., "The devastation of Bam: an overview of health issues 1 month after the earthquake", Journal of the royal institute of public health, 118, 403-408, 2004.

[2] Bakolas A, Biscontin G, Zendri E. Characterization of mortars from traditional buildings in seismic areas. PACT Revue du groupe europeen d'etudes pour les techniques physiques, chimiques, biologiques et mathematiques appliquees a l'archcologie 56,17-29, 1998.

[3] Barbat AH, Ye'pez F, Canas JA. Damage scenarios simulation for seismic risk assessment in urban zones. Earthquake Spectra ,12(3):371-94, 1996.

[4] Bertero, V. and Brokken, S., "Infills in Seismic Resistant Buildings", Journal of Struct. Eng., ASCE, 109 (6), 1337 - 61, 1983.

[5] Bozorgnia, Y. and Bertero, V., "Improved Shaking and damage Parameters for Post-Earthquake applications". Proceedings of the SMIP01 Seminar of Utiliration of Strong-Motion Data, Los Angeles, California, September 12, PP. 1-22, 2001.

[6] Cakmak AS, Erdik M, Moropoulou A. A joint program for the protection of the Justinian Hagia Sophia. In: Proceedings of the Fourth International Symposium on the Conservation of Monuments in the Mediterranean Basin, Rhodes, vol. 4, 1997.

[7] Colombo, A. and Negro, P. "A damage index of generalized applicability", Eng. Strct. 27, $1164-1174,2005$. 
[8] Durukal E, Cakmak AS, Yuzugullu O, Erdik M. Assessment of the earthquake performance of Hagia Sophia. PACT Revue du groupe europeen d'etudes pour les techniques physiques, chimiques, biologiques et mathematiques appliquees a l'archeologie , 56: 49-57, 1998.

[9] G.N.D.T. Seismic damage and vulnerability of the churches in Umbria. CD-Rom. Presidency from the Ministry Council [in Italian], 1998.

[10] Hossein Sadeghi, S.M. Fatemi Aghda, Sadaomi Suzuki, Takeshi Nakamura, "3-D velocity structure of the 2003 Bam earthquake area (SE Iran): Existence of a low-Poisson's ratio layer and its relation to heavy damage", Tectonophysics 417, 269-283, 2006.

[11] Iemura, H. and Mikami, T., "Demand Spectra of yield strength and ductility factor to satisfy the required seismic performance objectives." proceeding of International workshop on Annual commemoration of chichi Earthquake, Volume II - Technology Aspect, PP. 501 -508, 2000.

[12] Langa K, Bachmanna $\mathrm{H}$. On the seismic vulnerability of existing buildings: a case study of the city of Basel. Earthquake Spectra, 20(1):4366, 2004.

[13] Lourenc P.B., Roque J.A., "Simplified indexes for the seismic vulnerability of ancient masonry buildings", Construction and Building Materials 20, 200-208, 2006.

[14] Maheri M. R., "Seismic Vulnerability of post-Islamic Monumental Buildings in Iran, a Review of Historical Sources", Fifth International Conference of Seismology and Earthquake Engineering, Tehran, Islamic Republic of Iran, 2007(accepted paper).

[15] Motamed J., Adlparvar M., AlHussaini A., Vosoughifar H. R., Walls A., "Reconstruction and Retrofit of the Historical Monument of Arge Bam after Earthquake Damage", The first international congress on seismic retrofitting", Tehran, Iran, 2006.

[16] Papadopoulos, P. and Mitsopulou, A. and Athanatapulou, A. "Failure Indices for RLC Building Structures", published by Elsevier Science Ltd. 12th European Conference on Earthquake Engineering., 2003.

[17] Park, Y. - J., and Ang, A. H., "Seismic damage analysis of reinforced Concrete buildings". J. Struct. Eng., III(4) , 740 - 757, 1985.

[18] Rafaela Cardoso, Mário Lopes, Rita Bento, "Seismic evaluation of old masonry buildings. Part I: Method description and application to a casestudy", Engineering Structures 27, 2024-2035, 2005.

[19] Reinhorn, A. M., Valles, R. E., and Lysiak, M., "Simplified Inelastic Response Evaluation Using Composite Spectra", Earthquake Spectra, in review, 2003.

[20] Rita Bento, Mário Lopes, Rafaela Cardoso, "Seismic evaluation of old masonry buildings. Part II: Analysis of strengthening solutions for a case study", Engineering Structures 27, 2014-2023, 2005.

[21] Whitman RV, Reed JW, Hong ST. Earthquake damage probability matrices. Proceedings of the Fifth WCEE, Rome, Italy, 1972. 